\title{
Carbon Emissions from Livestock Manure in Arid Regions - Technical Study on the United Arab Emirates
}

\author{
Akinleye Sowunmi ${ }^{1}$, Juan-Rodrigo Bastidas-Oyanedel ${ }^{1} \&$ Jens Ejbye Schmidt $^{1}$ \\ ${ }^{1}$ Institute Center for Energy - iEnergy, Masdar Institute of Science and Technology, Abu Dhabi, United Arab \\ Emirates
}

Correspondence: Jens Ejbye Schmidt, Institute Center for Energy - iEnergy, Masdar Institute of Science and Technology, Abu Dhabi, United Arab Emirates. E-mail: jschmidt@masdar.ac.ae

\author{
Received: April 8, 2015 Accepted: April 23, 2015 Online Published: June 8, 2015 \\ doi:10.5539/enrr.v5n3p1 URL: http://dx.doi.org/10.5539/enrr.v5n3p1
}

\begin{abstract}
The United Arab Emirates (UAE) is acting to reduce its carbon footprint and promote sustainable development. In a bid to quantify and mitigate the emission of greenhouse gases (GHG), the government has recently compiled an inventory for GHG emissions from key sectors in Abu Dhabi Emirate. However, the inventory lacks data for several subsectors and for other emirates in the UAE. In this study, the trend of emissions in the UAE was analyzed, and carbon emission from livestock manure (sheep, goat, cattle and camel) was determined experimentally; and combined with a detailed livestock mapping to evaluate the total carbon emission from manure in the UAE. Results showed that total emission from sheep, goat, cattle and camel manure in the UAE are 22, 246, 56 and $11 \mathrm{kt} \mathrm{CO}$ eq. respectively; with Abu Dhabi Emirate contributing 84\%, 63\%, 52\% and 91\% for each livestock respectively. In total, Abu Dhabi Emirate contributes $212 \mathrm{kt} \mathrm{CO}_{2}$ eq. (64\%) to livestock emission in the UAE. These results can be further analyzed to model and predict the increase in emissions from this subsector and design strategies to combat these emissions.
\end{abstract}

Keywords: carbon emissions, livestock manure, greenhouse gas, climate change

\section{Introduction}

Over the last decade, climate change has become an issue of global discussion by individuals, companies, governments and international organizations (Brander et al., 2013); due to its environmental, social, economic and political effects (Karl \& Trenberth, 2003; Shah, 2015). The Intergovernmental Panel on Climate Change (IPCC) defined climate change as "any change in climate over time, whether due to natural variability or as a result of human activity." Greenhouse gases (GHG) are major drivers of climate change: due to their ability to trap heat around the earth's surface, leading to an increase in the average temperature of planet (global warming) (IPPC, 2007; IPCC, 2014; Mohr, 2005). GHG emissions from key sources in Abu Dhabi have been quantified, but emissions from other emirates in the United Arab Emirates (UAE) are yet to be quantified.

The UAE is a country with seven autonomous sheikhdoms. Abu Dhabi Emirate - one of the seven sheikhdoms constitutes $87 \%$ of the country's total area (excluding the islands) (SCAD, 2014a) and is home to $8 \%$ of the world's proven oil reserve (SCAD, 2013). Therefore, the UAE's energy sector is its most important sector in greenhouse gas emission, and this sector is primarily driven by Abu Dhabi's oil and gas activities. The livestock sector is also of high importance because it is regarded as one of the pillars of development and integration, and one of the country's most important agricultural activities (SCAD, 2014c).

The UAE has ratified several international treaties; all of which require a reduction in GHG emissions and a protection of the environment. These conventions include amongst others; the Vienna Convention for the Protection of Ozone Layer (1989), the Montreal Protocol on Substances that Deplete the Ozone Layer (1989, resigned in 2005), the Kyoto Protocol to the United Nations Framework Convention on Climate Change (2005), the United Nations Framework on Climate Change (1995) and the Basel Convention (1990) (Basel Convention, 2011; MEUAE, 2006; Trakhees, 2010; UAENBS, 2013b; WAM, 2005, 2014). The government is therefore seeking ways to reduce its emissions. According to IPCC (1996a), about $20 \%$ of anthropogenic GHG emissions come from agriculture. These in combination with UAE's commitment to agricultural development make it necessary to look into the sector's carbon emissions. Steps already taken by the government to achieve significant GHG reductions in its key sectors include: Masdar Initiative, Waste Management Strategy, Surface 
Transport Master Plan 2030, Ecological Footprint Initiative; inter alia (EAD, 2010; EAD, 2013; DTAD, 2009; Masdar, 2015).

GHG measurement is essential but expensive and thus has not been extensively implemented. The use of constant emission factors have proven insufficient for quantifying gas emissions due to the high variability in animal waste and several environmental factors affecting the conversion of manure to gases across farm facilities (Li et al., 2012). In this study, the GHG emission potential of livestock manure was experimentally determined. Results were used to evaluate the total GHG potential of livestock manure in Abu Dhabi and the UAE at large. For the purpose of this paper, livestock refers to sheep, goat, cattle and camel. Poultry and fishery are not included.

Although a GHG inventory has been collated for key sectors in Abu Dhabi, there is lack of data for other emirates in the UAE. In addition, the agricultural section of the inventory provides data for methane emission from manure management. This emission only covers those from collection and disposal of manure, and not emissions from the manure itself. Also of note are some important recommendations made by the inventory. They include: carrying out analysis in order to improve data and reduce uncertainties; and consideration of the use of alternative GHG inventory methodologies (EAD, 2012). This works seeks to bridge this gap of this lack of data for emissions from animal manure, and from other emirates in the UAE. The experimental analysis performed will also provide a base point for comparison when other methods are eventually used to determine the contribution of animal manure to carbon emissions.

\subsection{Status of Greenhouse Gas Emissions}

Figure 1A shows the carbon dioxide emissions from the energy sector (oil and gas; water and electricity production) from 2005 to 2013. The steady increase in emissions reflects the rise in population in the emirate and its greater demand for energy. Although population increased by about $70 \%$ during this period, emissions increased by only $30 \%$ (SCAD, 2012). This was as a result of the reduction in energy consumption (per capita) in the UAE which fell by 32\% between 2003 and 2010, and has continued to drop (WB, 2014). The observed reduction was due to efficiency measures taken by the government (UAEG20, 2012; UME, 2014). Figure 1B shows the emission (only methane and carbon dioxide emissions considered in this analysis) from important sectors in Abu Dhabi emirate for the year 2012. The energy sector includes emissions from subsectors: oil and gas, water and electricity, transport, manufacturing and construction, and other energy related sectors. Water and electricity production subsector has the highest amounts of emissions because of the heavy presence of water desalination in the UAE.
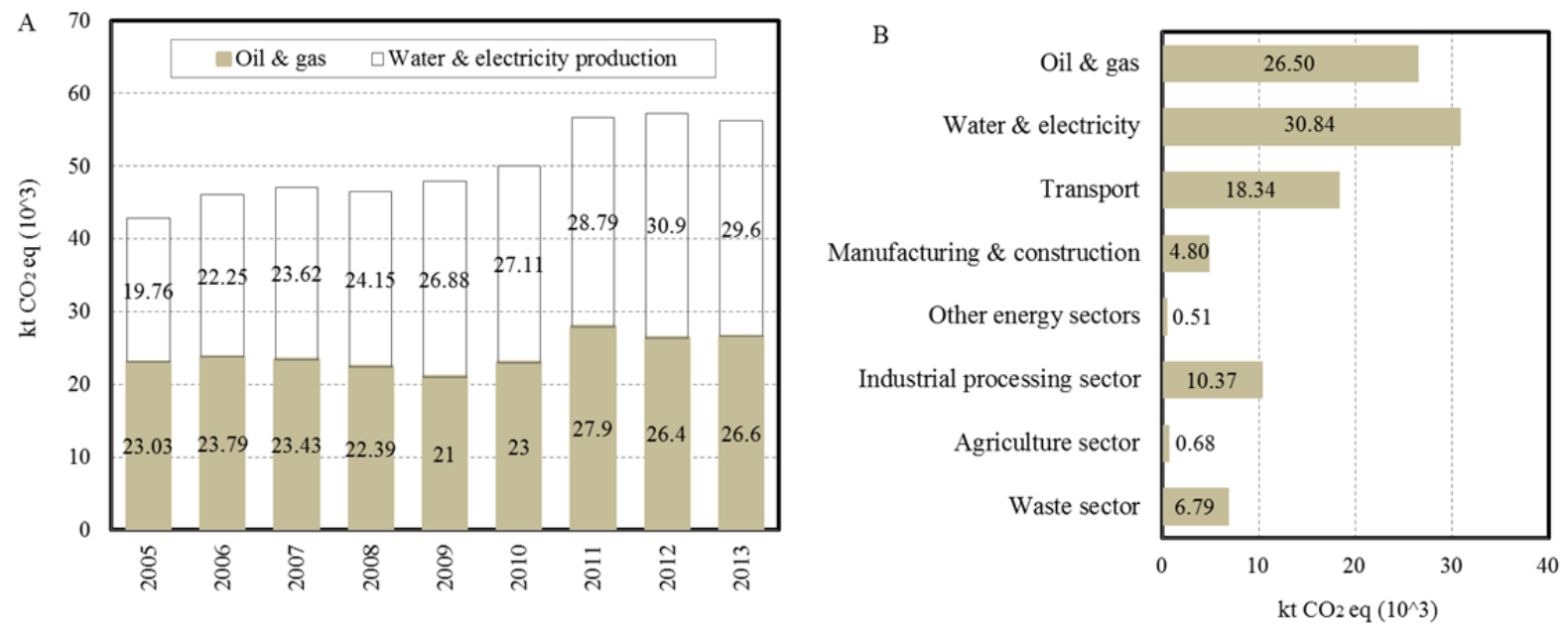

Figure 1. (A) Carbon dioxide emission from the energy sector (B) Quantity of greenhouse gas emission from important sectors in Abu Dhabi Emirate for the year 2012 (ADNOC, 2009; SCAD, 2014a)

\subsection{Climate Profile}

Table 1 shows five climate indicators for UAE in the year 2013. The average and absolute temperatures for the UAE are indicated, while the other indicators listed are for the Emirate of Abu Dhabi. The UAE experiences high summer temperatures from May to September, with July being the hottest month. In 2012, summer 
temperatures went as high as $49.3^{\circ} \mathrm{C}$, while the highest summer temperature experienced in the UAE was in July 2002 when the mercury hit $52.1^{\circ} \mathrm{C}$ (AW, 2015; Croucher, 2013). The Tropic of Cancer runs through the country's southern hemisphere, giving it a tropical desert climate with hot summers; hence the high summer temperatures. Although the objective of this paper is not to draw a line between emissions in the UAE and climate change, it is important to note that these increasing record temperatures call for actions to reducing emissions both locally and globally.

The weather in the UAE brings short and irregular rainfall as is typical in the Middle East. In 2013, Abu Dhabi experienced the highest amount of rainfall in November with $15.61 \mathrm{~mm}$ for four days, and a total of six months in the year with no rainfall. In 2011 however, the UAE experienced eight months without rainfall (NCMS, 2015; UAENBS, 2014).

The maximum absolute relative humidity for every month in the year 2013 was $90 \%$ and over. December experienced absolute relative humidity of $100 \%$. The effect of this high humidity is most pronounced during the summer months where the apparent temperature is higher, making high temperatures feel hotter (UAENBS, 2014).

Maximum wind speed reached 23 knots in November of 2013 while wind gust reached maximum speed of 32 knots in May and July of the same year. The average of sunshine hours per day was 10.5 hours in Abu Dhabi, and the maximum was 11.7 hours. Records in the UAE show that there were 65 days with fog (15 in Abu Dhabi), 40 days with thunderstorm (4 in Abu Dhabi), and only one day of sandy storm (none in Abu Dhabi) (UAENBS, 2014; WS, 2013). There were no snow days through the year.

Table 1. Climate indicators in the United Arab Emirates (UAE) (NCMS, 2015; UAENBS, 2014)

\begin{tabular}{|c|c|c|c|c|c|c|c|c|c|}
\hline \multirow{3}{*}{ Month } & \multicolumn{4}{|c|}{ Temperature ${ }^{\circ} \mathrm{C}$} & \multirow{3}{*}{$\frac{\text { Rainfall (mm) }}{\text { Daily }}$} & \multirow{2}{*}{\multicolumn{2}{|c|}{$\begin{array}{c}\text { Relative humidity } \% \\
\text { Absolute }\end{array}$}} & \multirow{3}{*}{$\begin{array}{c}\text { Sunshine hours } \\
\max \end{array}$} & \multirow{3}{*}{ Fog days } \\
\hline & \multicolumn{2}{|c|}{ Average } & \multicolumn{2}{|c|}{ Absolute } & & & & & \\
\hline & $\max$ & $\min$ & $\max$ & $\min$ & & $\max$ & $\min$ & & \\
\hline January & 21.17 & 18.74 & 31.4 & 5.1 & 0 & 99 & 14 & 9.3 & 6 \\
\hline February & 22.24 & 19.64 & 32 & 8.6 & 2.61 & 99 & 18 & 9.9 & 3 \\
\hline March & 24.63 & 22.41 & 37.1 & 11.4 & 0.6 & 98 & 7 & 10.8 & 2 \\
\hline April & 28.96 & 26.59 & 43 & 15.5 & 12.26 & 90 & 9 & 11 & 0 \\
\hline May & 32.25 & 29.33 & 44.5 & 20.1 & 0.02 & 91 & 7 & 11.7 & 0 \\
\hline June & 34.19 & 31.86 & 45.4 & 21.32 & 0 & 99 & 9 & 11.7 & 1 \\
\hline July & 37.70 & 32.05 & 48.8 & 23.3 & 0 & 92 & 9 & 11.6 & 0 \\
\hline August & 36.58 & 31.63 & 46 & 26.94 & 0.01 & 92 & 10 & 10.8 & 0 \\
\hline September & 34.07 & 31.57 & 44.9 & 23 & 0 & 92 & 12 & 10.4 & 0 \\
\hline October & 30.76 & 28.54 & 41.9 & 20 & 0 & 96 & 10 & 10 & 1 \\
\hline November & 26.26 & 23.95 & 38 & 13.2 & 15.61 & 95 & 16 & 9.4 & 0 \\
\hline December & 22.54 & 19.85 & 32.8 & 5.7 & 0 & 100 & 19 & 9.1 & 2 \\
\hline
\end{tabular}

Temperature values are for the UAE while the other indicators are for the Emirate of Abu Dhabi.

\subsection{Livestock Mapping}

Livestock considered for analysis include sheep, goat, cattle and camel. Figure 2 shows the distribution of livestock in the UAE from 2006 to 2012. It can be observed that the quantity of cattle and camel remained fairly constant during the period, while there was an increase in sheep. The decline in the number of goats from 2011 to 2012 is attributed to the export ban imposed by India and Pakistan (Sathish, 2011). In 2012; 84\%, 63\%, 51\% and $91 \%$ of sheep, goat, cattle and camel in the UAE respectively, were bred in Abu Dhabi. 


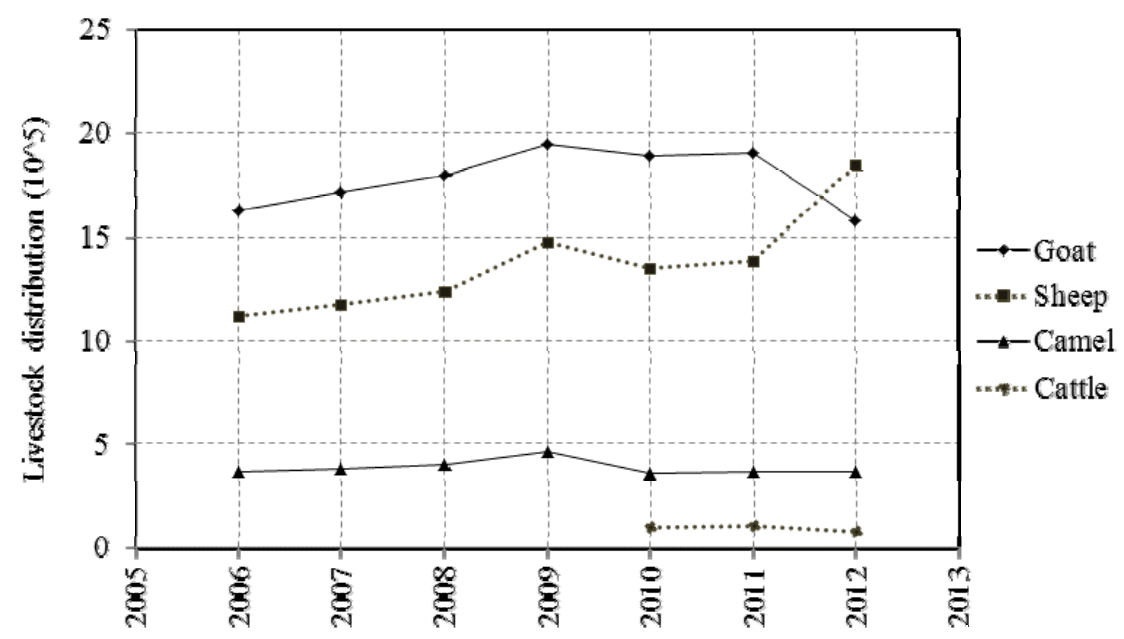

Figure 2. Livestock distribution in the UAE for year (SCAD, 2014b; UAENBS, 2013a, UAENBS, 2013c)

\subsection{Carbon Emissions from Livestock}

Literature is focused on the measurement of enteric emissions from ruminants. Several methods have been developed for the measurement of enteric fermentation. IPCC proposed two general methods - Tier 1 and Tier 2 - for the estimation of enteric emissions. Tier 1 uses default emission factors while Tier 2 involves the use of country-specific information to calculate the emission factors (Gibbs et al., 2000). A global protocol for community-scale greenhouse gas emission (GPC) has also been developed to help cities to effectively manage emissions by first measuring and reporting these emissions $(C 40,2012)$. Other computational and empirical methods have equally been employed in research (Fauser et al., 2011; Sejian et al., 2011); however, not much has been done in determining the potential emission from livestock manure.

\section{Materials and Methods}

\subsection{Determination of Greenhouse Gas Emissions Potential of Livestock Manure}

The purpose of the experiment was to simulate methane and carbon dioxide emissions from sheep, goat, cattle and camel manure in a laboratory environment. Therefore, $328 \mathrm{~mL}$ serum bottles were labelled and weighed prior to the visit to Al Mina Automated Slaughter House, where livestock manure was collected. Serum bottles three for each manure type - were partially loaded with manure taken at the point of excretion, and immediately sealed using a rubber septum and screw cap. Loaded serum bottles were weighed to determine the quantity of manure in each, and then stored in the laboratory to allow for decomposition in a process that transitioned from aerobic to anaerobic at $30^{\circ} \mathrm{C}$. This creates similar situation to the central manure collection center where the topmost part of the waste is exposed to air while the underside is not. The process was allowed to run until there was no significant increase in gas production. A gas chromatograph (GC, SRI 8610C Instruments, 3" Silica Gel column) equipped with a flame ionization detector (FID) and thermal conductivity detector (TCD) were respectively used to measure the methane and carbon dioxide content in the headspace of the serum bottles. The quantified methane and carbon dioxide were then used to estimate the volume of GHG in the serum bottle headspaces. GHG production was calculated by dividing gas production (L) by the wet solid loading (kg-WS).

\subsection{Estimation of Total Greenhouse Gas Emissions}

The total number of each livestock in Abu Dhabi and the UAE was obtained from the mapping. Cattle of different age groups in the UAE are either held in traditional holdings or commercial farms. In estimating the emissions from cattle manure, the following assumptions were made: GHG emission potential for manure from cattle across all age groups is the same; all dairy cattle in Al Ain Dairy Farm (6000 herd) (Underwood, 2013) and Al Rawabi Dairy Farm (11000 herd) (Malek, 2013) are held in commercial farms, and every other cattle is classified as beef cattle; fallen stock were not taken into consideration; variation in number of cattle although the year due to slaughter was not taken into account.

The average quantity of manure produced by a lactating cattle per head per day is $70 \mathrm{~kg}$ (Weiss \& St-Pierre, 2010). For beef cattle, Euken (2009) reported that beef cattle between $363-567 \mathrm{~kg}$ of weight excrete $30 \mathrm{~kg}$ of dung per day while those ranging from $227-363 \mathrm{~kg}$ excrete $25 \mathrm{~kg} \cdot(\text { day })^{-1}$. ODV (2015) reported that beef cattle of $454 \mathrm{~kg}$ excrete $27 \mathrm{~kg}$ of total dung per day; therefore, this analysis assumed a value of $27 \mathrm{~kg} \cdot(\text { day })^{-1}$ for beef 
cattle. The total equivalent volume of $\mathrm{CO}_{2}$ emission from cattle manure in $\mathrm{L} \cdot(\text { day })^{-1}$ was estimated using the developed equation 1 .

$$
\mathrm{V}_{\mathrm{T}, \mathrm{CO} 2, \mathrm{eq}}=\left(21 \mathrm{P}_{\mathrm{CH} 4, \mathrm{C}}+\mathrm{P}_{\mathrm{CO} 2, \mathrm{C}}\right) \times\left[\left(\mathrm{N}_{\mathrm{dc}} \cdot \mathrm{A}_{\mathrm{dc}}\right)+\left(\mathrm{N}_{\mathrm{bc}} \cdot \mathrm{A}_{\mathrm{bc}}\right)\right]
$$

$\mathrm{V}_{\mathrm{T}, \mathrm{CO} 2 \text {,eq }}$ is the total equivalent volume of $\mathrm{CO}_{2}$ emission per day. $\mathrm{P}_{\mathrm{CH} 4, \mathrm{C}}$ and $\mathrm{P}_{\mathrm{CO} 2, \mathrm{C}}$ represent respectively, the $\mathrm{CH}_{4}$ and $\mathrm{CO}_{2}$ potential of cattle in $\mathrm{L} \cdot(\mathrm{kg}-\mathrm{WS})^{-1} \cdot \mathrm{N}_{\mathrm{dc}}$ and $\mathrm{A}_{\mathrm{dc}}$ represent the total number of dairy cattle and average quantity of manure produced per head per day respectively. Subscript 'bc' stands for beef cattle. The total equivalent quantity of $\mathrm{CO}_{2}$ emission from cattle manure in $\mathrm{kt} \cdot(\text { day })^{-1}$ was estimated using the ideal gas equation as shown in equation 2 .

$$
\mathrm{m}_{\mathrm{T}, \mathrm{CO} 2, \mathrm{eq}}=(\mathrm{PM} / \mathrm{RT}) \times \mathrm{V}_{\mathrm{T}, \mathrm{CO}, \mathrm{eq}}
$$

$\mathrm{P}, \mathrm{M}, \mathrm{R}$ and $\mathrm{T}$ represent atmospheric pressure, molecular weight $\left(\mathrm{CO}_{2}\right)$, universal gas constant and temperature respectively. The total GHG emission from sheep, goat and camel manure were estimated using equations 1 and 2. Literature reported the average quantity of manure excreted from sheep, goat and camel to be 1.1, 2.6 and 4 $\mathrm{kg} \cdot(\text { day })^{-1}$ respectively (BAE, 2014; Rosillo-Calle, 2007).

\section{Results and Discussion}

Figure 3 shows the $\mathrm{CH}_{4}$ and $\mathrm{CO}_{2}$ content from three serum bottles with different manure loadings. The specific methane production in all three serum bottles was fairly constant through the digestion period. $\mathrm{CO}_{2}$ yield was observed to show inhibition with loading. Serum bottle with highest manure loading produced lowest $\mathrm{CO}_{2}$ volume, and vice-versa. It may be proposed that some of the $\mathrm{CO}_{2}$ produced remained in the liquid phase due to insufficient headspace, and therefore, were not captured in the measurement. Sheep, goat and camel manure showed similar gas production pattern (data not shown). Table 2 shows the specific GHG potential $\left(\mathrm{CH}_{4}\right.$ and $\mathrm{CO}_{2}$ ) for livestock manure. Goat manure showed the highest GHG potential while camel manure had the lowest. This may be used as indication to determine the extent to which livestock conserve nutrients. In this case, camel is most effective in conserving its nutrients.

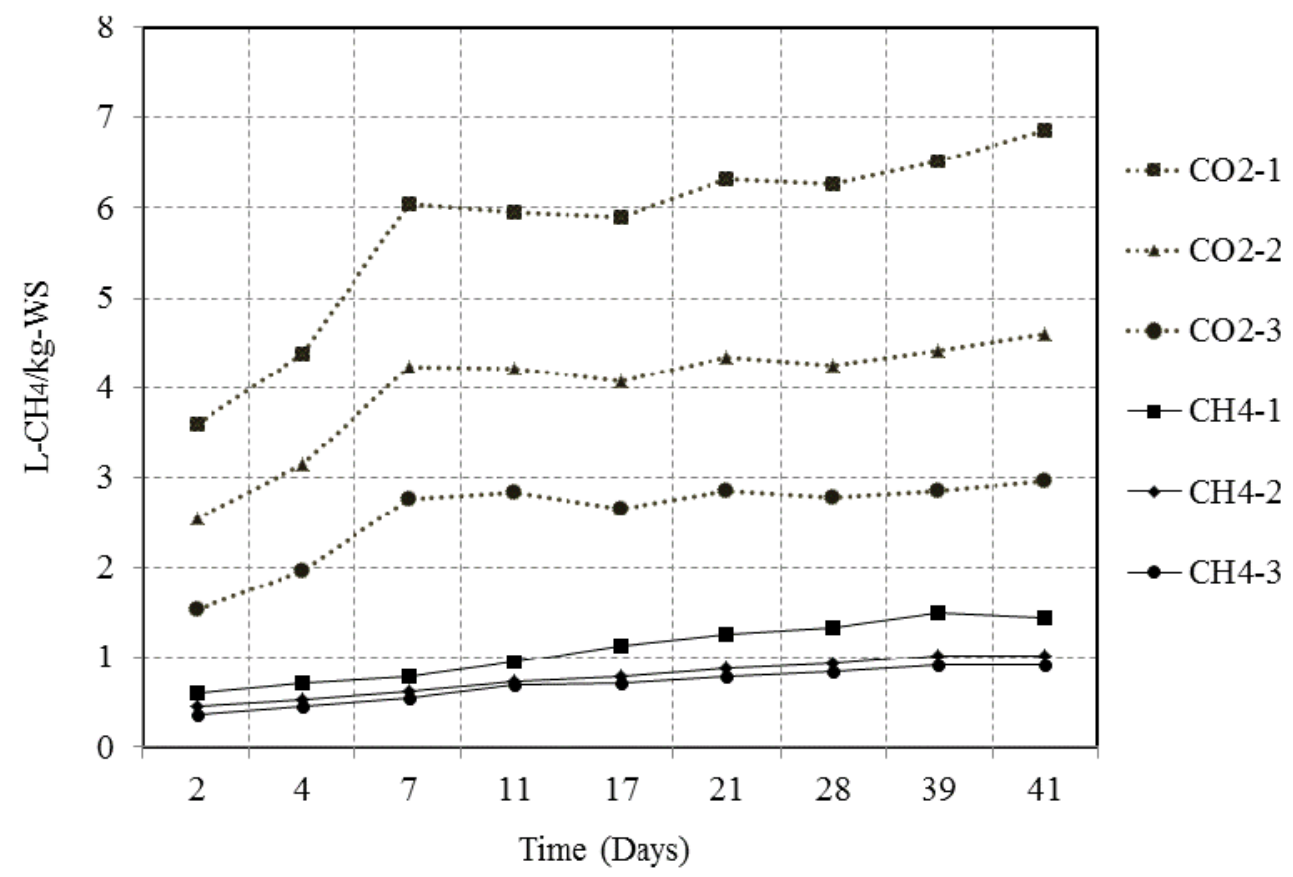

Figure 3. Carbon dioxide and methane potential of cattle manure. Suffix ' 1 ' represents load 1 which had the lowest manure loading, and vice-versa for suffix 3. CO2-1 and CH4-1 represent greenhouse gas emissions from bottle 1

Serum bottle with the lowest loading represents the closest case to reality where excreted manure is exposed to an infinite supply of air. The specific quantity of $\mathrm{CH}_{4}$ and $\mathrm{CO}_{2}$ produced in the lowest loading was therefore used for further analysis. 
Table 2. Specific greenhouse gas potential of livestock manure

\begin{tabular}{lllll}
\hline $\mathrm{L} \cdot(\mathrm{kg}-\mathrm{WS})^{-1}$ & Sheep manure & Goat manure & Cattle manure & Camel manure \\
\hline $\mathrm{CH}_{4}$ & 0.4 & 3.97 & 1.15 & 0.01 \\
$\mathrm{CO}_{2}$ & 8.07 & 10 & 6.86 & 11.06 \\
$\mathrm{CO}_{2}$ eq. & 16.47 & 93.37 & 31.01 & 11.27 \\
\hline
\end{tabular}

Table 3 shows a sample calculation of GHG emission from cattle manure in Abu Dhabi and the UAE for the year 2012. Emissions for sheep, goat and camel were estimated using the same steps (data not shown).

Table 3. Estimation of carbon emissions from cattle manure generated in Abu Dhabi Emirate \& the UAE

\begin{tabular}{|c|c|c|}
\hline & Abu Dhabi & UAE \\
\hline Total number of dairy cattle & 6,000 & 15,684 \\
\hline Total number of beef cattle & 38,778 & 63,033 \\
\hline \multicolumn{3}{|l|}{ Average manure excreted per head } \\
\hline Dairy cattle (kg-WS/head/d) & 70 & 70 \\
\hline Beef cattle (kg-WS/head/d) & 27.39 & 27.39 \\
\hline \multicolumn{3}{|l|}{ Total manure excreted per year } \\
\hline Dairy cattle manure (kg-WS/d) & 420,000 & $1,097,880$ \\
\hline Beef cattle manure (kg-WS/d) & $1,062,181$ & $1,726,558$ \\
\hline $\mathrm{CH}_{4}$ potential of manure $(\mathrm{L} / \mathrm{kg}-\mathrm{WS})$ & 1.15 & 1.15 \\
\hline $\mathrm{CO}_{2}$ potential of manure $(\mathrm{L} / \mathrm{kg}-\mathrm{WS})$ & 6.86 & 6.86 \\
\hline Total $\mathrm{CO}_{2}$ eq. (L/kg-WS) & 30.96 & 30.96 \\
\hline \multicolumn{3}{|l|}{ Total $\mathrm{CO}_{2}$ eq. emission } \\
\hline Dairy cattle (L/d) & $13,001,213$ & $33,985,170$ \\
\hline Beef cattle (L/d) & $32,880,101$ & $53,446,063$ \\
\hline Total cattle $\mathrm{CO}_{2}$ eq. emission $(\mathrm{L} / \mathrm{d})$ & $45,881,314$ & $87,431,233$ \\
\hline Pressure (atm) & 1.01 & 1.01 \\
\hline Molecular weight $\mathrm{CO}_{2}(\mathrm{~g} / \mathrm{mole})$ & 44.01 & 44.01 \\
\hline $\mathrm{R}(\mathrm{L} \cdot \mathrm{atm} / \mathrm{mol}-\mathrm{K})$ & 0.08 & 0.08 \\
\hline Temperature (K) & 310 & 310 \\
\hline Density $\mathrm{CO}_{2}(\mathrm{~g} / \mathrm{L})$ & 1.75 & 1.75 \\
\hline Total cattle $\mathrm{CO}_{2}$ eq. emission $(\mathrm{g} / \mathrm{d})$ & $80,332,336$ & $153,080,952$ \\
\hline Total cattle $\mathrm{CO}_{2}$ eq. emission (kt/y) & 29.32 & 55.87 \\
\hline
\end{tabular}

WS - wet solid; R - Universal Gas Constant.

Figure 4 shows the GHG emissions from sheep, goat, cattle and camel manure from Abu Dhabi and other Emirates in the UAE for the year 2012. The percentage contribution from Abu Dhabi Emirate is also indicated on the plot. In total, Abu Dhabi Emirate contributes $64 \%$ of the GHG emission from livestock in the UAE. It should be noted that the experiments do not completely reflect a true-life scenario where manure's interaction with environment is unobstructed. All data presented here represent an attempt to quantify the maximum carbon 
emission from animal manure. The method is reproducible and can be used in other laboratories for similar analysis. It is also an expectation that the availability of such data will stimulate the development of farm-based biogas digesters in the UAE.

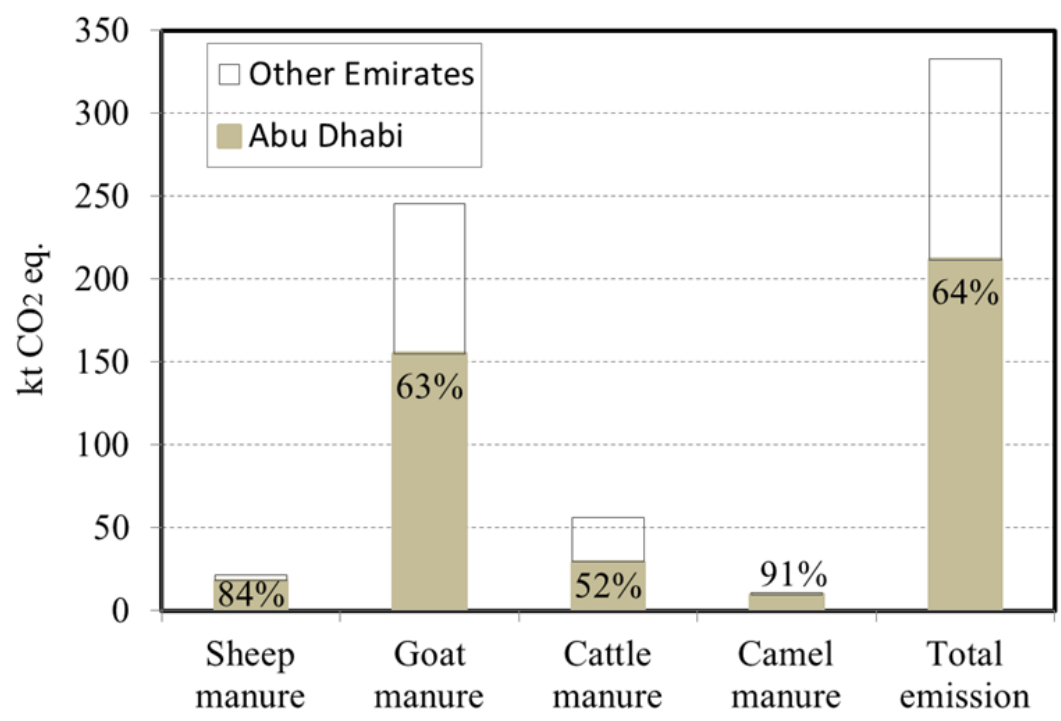

Figure 4. Greenhouse gas emission from livestock manure in the UAE

The use of experiments in determining GHG emissions is uncommon. Researchers have mostly adopted computational techniques in estimating emissions from livestock manure systems. Some of these have included farm-scale emission models which were constructed using a variety of methodologies including empirical equations, emission factors and process-oriented mechanisms.

Rotz et al. (2010) evaluated GHG emissions from dairy production using the DairyGHG software. This was based on milk production and cannot easily be compared to the analysis done here. Li et al. (2012) presented several scenarios using the Manure-DNDC model. A comparable scenario simulates emissions from a feedlot at the University of California at Davis at temperature of $19.5^{\circ} \mathrm{C}$. Carbon emissions of $1 \mathrm{~kg} / \mathrm{head} / \mathrm{day}$ and 0.055 $\mathrm{kg} / \mathrm{head} /$ day were obtained for $\mathrm{CO} 2$ and $\mathrm{CH} 4$ respectively. These were converted into comparable units using the ideal gas equation to obtain $2003 \mathrm{~L} /$ head/day and $110 \mathrm{~L} /$ head/day respectively. At 6000 dairy cattle head per day, a total of $12,678,000 \mathrm{~L} /$ day of $\mathrm{CO}_{2}$ was obtained which is comparable to the value of 13,001,213 obtained in this report (see table 3). The difference will be as a result of the different temperatures at play. Phetteplace et al. (2001) also computed emissions from dairy and cattle manure. Temperature was not specified and was assumed in this study to be $25^{\circ} \mathrm{C}$ for the purpose of analysis. Emissions estimated from dairy and stocker breeds were found to be $16,597,989 \mathrm{~L} /$ day and $25,268,443 \mathrm{~L}$ /day respectively. This shows that higher temperatures obtainable in arid regions such as Abu Dhabi do not necessarily lead to greater emissions from livestock manure.

Other models include CEFM used in Mangino et al. (2007), CONCEPT in Zhang et al. (2005), ACES in Cortus et al. (2007), TwoFilm in De Visscher et al. (2002), FarmGHG in Olesen et al. (2006), and FARMING in Van Evert et al. (2003) and Schils et al. (2005). These models have mostly focused on cattle manure and more specifically, dairy cattle manure in some cases. Possible mitigation strategies for estimated emissions from livestock manure systems have been highlighted in literature and can be utilized to combat expected increase in emissions (Cole et al., 1997; Hartung \& Phillips, 2002; Phetteplace et al., 2001).

\section{Conclusions}

The United Arab Emirates (UAE) has become environmentally aware and is seeking ways to reduce its carbon footprint for a sustainable future. In this light, an inventory of greenhouse gas (GHG) emissions for the most important sectors in Abu Dhabi Emirate have been collated; however, data gaps exist in the subsectors, and for emissions from other emirates.

The current trend of GHG emission in the UAE was analyzed in this work; a livestock mapping was conducted; and the total carbon emission from livestock manure was determined experimentally. Livestock mapping for the 
year 2012 showed that there were 1,841,829 sheep; 1,579,164 goats; 78,717 cattle; and 364,378 camels in the UAE. The total volume of carbon emissions produced were respectively $22,246,56$ and $11 \mathrm{kt} \mathrm{CO}_{2}$ eq. for the same year. The contribution of carbon emissions from animal manure in Abu Dhabi Emirate were respectively $84 \%, 63 \%, 52 \%$ and $91 \%$ of the total produced in the UAE. Abu Dhabi Emirate contributed $64 \%$ to the total emission from livestock manure in the UAE, with goat manure contributing the highest volume.

The obtained results can be used to model expected increase in carbon emissions from the livestock subsector of agriculture, and eventually lead to the design of possible mitigation strategies. Such strategies can include the establishment of farm-based biogas plants for processing the animal manure to generate in-house energy, and digestate as fertilizer.

\section{Acknowledgements}

The authors would like to acknowledge the financial support from Masdar Institute, Project 2BIONRG (12KAMA4), to help fulfill the vision of the late President Sheikh Zayed Bin Sultan Al Nahyan for sustainable development and empowerment of the United Arab Emirates and humankind. The authors acknowledge the Abu Dhabi Municipal Slaughtering houses, and the Al Ain animal Market for allowing the sampling collection.

\section{References}

ADNOC. (2009). Sustainability Report. Abu Dhabi National Oil Company.

AW. (2015). Abu Dhabi Local Weather. AccuWeather. Retrieved March 30, 2015, from http://www.accu weather.com/en/ae/abu-dhabi/321626/august-weather/321626?monyr=8/1/2013\&view=table

BAE. (2014). Animal and Poultry Manure Production and Characterization. Bio\&Ag Engineering and NC State University. Retrieved March 30, 2015, from http://www.bae.ncsu.edu/topic/animal-waste-mgmt/program/ land-ap/barker/a\&pmp\&c/content.htm

Basel Convention. (2011). Conference of the Parties. Retrieved March 30, 2015, from http://www.basel.int/ TheConvention/ConferenceoftheParties/OverviewandMandate/tabid/1316/Default.aspx

Brander, M., Carstairs, S., \& Topp, C. F. (2013). Global protocol for community scale greenhouse gas emissions: a trial application in the West Highlands of Scotland. Greenhouse Gas Measurement and Management, 3(3-4), 149-165. http://dx.doi.org/10.1080/20430779.2013.877313

C40. (2012). Global Protocol for Community-Scale Greenhouse Gas Emissions. C40 Cities Climate Leadership Group, ICLEI Local Goverments for Sustainability and World Resources Institute. Retrieved March 30, 2015, from http://www.ghgprotocol.org/files/ghgp/GPC_PilotVersion_1.0_May2012_20120514.pdf

Cole, C. V., Duxbury, J., Freney, J., Heinemeyer, O., Minami, K., Mosier, A., ... \& Zhao, Q. (1997). Global estimates of potential mitigation of greenhouse gas emissions by agriculture. Nutrient Cycling in Agroecosystems, 49(1-3), 221-228. http://dx.doi.org/10.1023/a:1009731711346

Cortus, E. L., Jacobson, L. D., Hetchler, B. P., \& Heber, A. J. (2010). National air emissions monitoring study: emissions data from two Freestall Dairy Barns in Wisconsin Site WI5B. Final Report. Purdue University, West Lafayette, IN, July, 2.

Croucher M. (2013). UAE Weather: Temperature Soars to Near Record Level. The National UAE. Retrieved March 30, 2015, from http://www.thenational.ae/news/uae-news/uae-weather-temperature-soars-to-nearrecord-level

DTAD. (2009). Surface Transport Master Plan: A Vision Connecting Abu Dhabi. Department of Transport Abu Dhabi.

EAD. (2010). UAE Ecological Footprint Initiative. Environmental Agency - Abu Dhabi.

EAD. (2012). Greenhouse Gas Inventory for Abu Dhabi Emirate. Environmental Agency - Abu Dhabi.

EAD. (2013). Towards Integrated Waste Management in Abu Dhabi. Environmental Agency - Abu Dhabi.

Euken, R. (2009). Managing Manure from Beef Feedlots for Crop Production. In Proc. Cattle Feeder's Conference: A New Era of Management. Iowa, USA.

Fauser, P., Sorensen, P., Nielsen, M., Winther, M., Plejdrup, M., Hooffman, L., ...Nielsen, O. K. (2011). Monte Carlo (Tier 2) Uncertainty Analysis of Danish Greenhouse Gas Emission Inventory. Greenhouse Gas Measurement and Management, 1(3-4), 145-160. http://dx.doi.org/10.1080/20430779.2011.621949

Gibbs, M. J., Coneely, D., Johnson, D., Lasse, K. R., \& Ulyatt, M. J. (2000). $\mathrm{CH}_{4}$ Emission from enteric fermentation. Good Practice Guidance and Uncertainty Management in National Greenhouse Gas 
inventories (IPPC). Retrieved March 30, 2015, from http://www.ipcc-nggip.iges.or.jp/public/gp/bgp/4_1_ CH4_Enteric_Fermentation.pdf

Hartung, J., \& Phillips, V. R. (2002). Control of Gaseous Emissions from Livestock Buildings and Manure Stores. Journal of Agricultural Engineering Research. 57(3), 173-189. http://dx.doi.org/10.1006/jaer.1994.1017

IPCC (Intergovernment Panel for Climate Change). (2007). Climate Change 2007: Synthesis Report. Intergovernmental Panel on Climate Change.

IPCC (Intergovernment Panel for Climate Change). (1996a). Technologies, policies and measures for mitigating climate change, Technical Paper 1. United Nations, New York

IPCC (Intergovernment Panel for Climate Change). (2014). Climate Change 2014: Impacts, Adaptation, and Vulnerability (Summary for Policymakers). Intergovernmental Panel on Climate Change.

Karl, T. R., \& Trenberth, K. E. (2003). Modern Global Climate Change. Science, 302(5651), 1719-1723. http://dx.doi.org/10.1126/science.1090228

Li, C., Salas, W., Zhang, R., Krauter, C., Rotz, A., \& Mitloehner, F. (2012). Manure-DNDC: a biogeochemical process model for quantifying greenhouse gas and ammonia emissions from livestock manure systems. Nutrient Cycling in Agroecosystems, 93(2), 163-200. http://dx.doi.org/10.1007/s10705-012-9507-z

Malek, C. (2013). Cows at Dubai Farm Get Cold Showers to Produce More Milk. The National UAE. Retrieved March 30, 2015, from http://www.thenational.ae/news/uae-news/cows-at-dubai-farm-get-cold-showers-to -produce-more-milk

Mangino, J., Peterson, K., \& Jacobs, H. (2007). Development of an emissions model to estimate methane from enteric fermentation in cattle. Retrieved from http://www.epa.gov/ttn/chief/con/conference/ei12/green/ mangino.pdf

Masdar. (2015). In Masdar, a mubadala company. Retrieved March 30, 2015, from http://www.masdar.ae

MEUAE. (2006). Initial National Communication to the United Nations Framework Convention on Climate Change. Ministry of Energy, UAE.

Mohr, N. (2005). A New Global Warming Strategy. EarthSave International. Retreived March 30, 2015, from http://www.earthsave.org/news/earthsave_global_warming_report.pdf

NCMS. (2015). Aviation Meteorology. National Center of Meteorology and Seismology. Retrieved March 30, 2015, from http://www.avmet.ae/default.aspx

ODV. (2015). Dairy Facilities Bottlenecks, Benefits, and Beyond. ODV Meeting. Retrieved March 30, 2015, from http://www.ohiodairyvets.org/uploads/2/4/1/4/24141277/odv_2012_-_program_documents.pdf

Olesen, J. E., Schelde, K., Weiske, A., Weisbjerg, M. R., Asman, W. A. H., \& Djurhuus, J. (2006). Modelling greenhouse gas emissions from European conventional and organic dairy farms. Agric Ecosyst Environ 112, 207-220. http://dx.doi.org/10.1016/j.agee.2005.08.022

Phetteplace, H. W., Johnson, D. E., \& Seidl, A. (2001). Greenhouse gas emissions from simulated beef and dairy livestock systems in the United States. Nutr Cycl Agroecosyst, 60, 99-102. $\mathrm{http}: / / \mathrm{dx}$. doi.org/10.1023/A:1012657230589

Rosillo-Calle, F. (2007). The Biomass Assessment Handbook: Bioenergy for a sustainable environment. London: Earthscan.

Rotz, C. A., Montes, F., \& Chianese, D. S. (2010). The carbon footprint of dairy production systems through partial life cycle assessment. J Dairy Sci, 93, 1266-1282. http://dx.doi.org/10.3168/jds.2009-2162

Sathish, V. M. (2011). UAE livestock prices are three times costlier. Emirates247. Retrieved March 30, 2015, from http://www.emirates247.com/news/emirates/uae-livestock-prices-are-three-times-costlier-2011-08-151.413459

SCAD. (2012). Preliminary Population Estimates: Mid-year 2012. Statistics Center Abu Dhabi.

SCAD. (2013). Energy and Environment Statistics 2012. Statistics Center Abu Dhabi.

SCAD. (2014a). Environment in Figures 2013. Statistics Center Abu Dhabi.

SCAD. (2014b). Livestock Statistics (2010 - 2013). Statistics Center Abu Dhabi.

SCAD. (2014c). Livestock Statistics 2013. Statistics Center Abu Dhabi. 
Schils, R. L. M., Verhagen, A., Arts, H. F. M., \& Sebek, L. B. J. (2005). A farm level approach to define successful mitigation strategies for GHG emissions from ruminant livestock systems. Nutr Cycl Agroecosyst, 71, 163-175. http://dx.doi.org/10.1007/s10705-004-2212-9

Sejian, V., Lal, R., Lakritz, J., \& Ezeji, T. (2011). Measurement and prediction of enteric methane emission. International Journal of Biometeorology, 55(1), 1-16. http://dx.doi.org/10.1007/s00484-010-0356-7

Shah, A. (2015) Climate Change and Global Warming. Global Issues. Retrieved March 30, 2015, from http://www.globalissues.org/issue/178/climate-change-and-global-warming

Trakhees. (2010). Montreal Protocol for Ozone Depleting Substances Issued by: Environment Department. Department of Planning \& Development Ports, Customs \& Free Zone Corporation, Government of Dubai.

UAEG20. (2012). Clean Energy and Energy Efficiency. UAE@G20. Retrieved Match 30, 2015, from http://www.uaeg20.ae/en/clean-energy-and-energy-efficiency

UAENBS. (2013a). Commercial farms survey (2010 - 2012). UAE National Bureau of Statistics.

UAENBS. (2013b). International Treaties and Agreements. UAE National Bureau of Statistics.

UAENBS. (2013c). Livestock Statistics (2007 - 2012). UAE National Bureau of Statistics.

UAENBS. (2014). Climate Statistics (2009-2013). UAE National Bureau of Statistics.

UME. (2014). UAE Residents Reduce Power and Water Consumption. Utilities-ME. Retrieved March 30, 2015, from http://www.utilities-me.com/article-2901-uae-residents-reduce-power-and-water-consumption/

Underwood, M. (2013). How to Keep 6,000 Cows Happy in the UAE Desert. The National UAE. Retrieved March 30, 2015, from http://www.thenational.ae/news/uae-news/how-to-keep-6-000-cows-happy-in-the -uae-desert

Van Evert, F. K., Ten Berge, H. F., Van Der Meer, H. G., Rutgers, B., Schut, A. G., \& Ketelaars, J. J. (2003) FARMIN: modeling crop livestock nutrient flows. ASA-CSSA-SSSA, Madison, WI, Annual meeting abstracts, November 2-6

Visscher, A. D., Harper, L. A., Westerman, P. W., Liang, Z., Arogo, J., Sharpe, R. R., \& Cleemput, O. V. (2002). Ammonia emissions from anaerobic swine lagoons: Model development. Journal of Applied Meteorology, 41(4), 426-433. http://dx.doi.org/10.1175/1520-0450(2002)0412.0.co;2

WAM. (2005). Khalifa issues decree ratifying Kyoto protocol. Emirates News Agency. Retrieved March 30, 2015, from http://www.wam.ae/en/news/emirates/1395227349412.html

WAM. (2014). U.A.E. reiterates commitment to Vienna Convention for the Protection of the Ozone Layer. Emirates News Agency. Retrieved March 30, 2015 from http://www.wam.ae/en/news/general-emirates -international/1395269669818.html

WB. (2014). Electric Power Consumption (kWh per capita). The World Bank. Retrieved March 30, 2015, from http://data.worldbank.org/indicator/EG.USE.ELEC.KH.PC

Weiss, W. P., St-Pierre, N. (2010). Feeding Strategies to Decrease Manure Output of Dairy Cows. WCDS Advances in Dairy Technolgy, 22, 229-237. Retrieved March 30, 2015, from http://www.wcds.ca/proc/ 2010/Manuscripts/p229-237Weiss.pdf

WS. (2013). Historical Weather for 2013 in Abu Dhabi, United Arab Emirate. WeatherSpark. Retrieved March 30, 2015, from https://weatherspark.com/history/32850/2013/Abu-Dhabi-United-Arab-Emirates

Zhang, R., Fadel, J., Rumsey, T., Xin, H., Arogo, J., Wang, Z., \& Mansell, G. (2005). An improved process based ammonia emission model for agricultural sources-model development. Prepared for presentation at the 14th International Emission Inventory Conference, Las Vegas, NV, March.

\section{Copyrights}

Copyright for this article is retained by the author(s), with first publication rights granted to the journal.

This is an open-access article distributed under the terms and conditions of the Creative Commons Attribution license (http://creativecommons.org/licenses/by/3.0/). 